\title{
The Language and Social Issues in Early Childhood (Observations at TK-IT Ar-Rahmah Padang)
}

\author{
Dessy Amelia
}

\author{
Early Childhood Education Department, Faculty of Education, Padang State University, Padang, Indonesia, \\ Mahirakhairanil@gmail.com
}

\begin{abstract}
Language and social is a very important thing to learn to add to the knowledge gained, then a study of the symptoms of language and social studies are held for some analysis of the weaknesses in speaking (speaking) vocabulary, slow language developing in speaking, often talking irregularly, not concentrating in accepting a word (language) from parents/teachers. developmental language and speech characteristics in children aged 5 years; namely: Mastering 1500 or more vocabulary words, telling stories that he already has known when looking at the image in the picture, mentioning the usefulness of something; ball to roll, bed to sleep, recognize and mention four to eight colors, understand simple jokes, compose jokes and puzzles.
\end{abstract}

Keywords: language, social, early childhood

\section{INTRODUCTION}

In this paper the author describes one early childhood development, namely language and social. Special discussion in this paper is explained in language and social problems in early childhood with the observation in kindergarten IT Ar-Rahmah Padang.

Humans may think because they have a language, whereas language is a language instinct animal that does not need to be learned and taught. The human language is the result of culture must be learned and taught. With human language to communicate. Therefore, language is the most important tool for humans.

Social development of children can be seen from the level of their ability to relate to others and become a productive member of society. This includes how a child learns to have a confidence in the behavior and relationships. Knowledge of developmental stages of behavior can help us to understand the actions of each child and provide experiences that will support positive social development.

By knowing the stages of child development can also help us pinpoint the problem or disorder of language and social development. Social development includes changes to increase knowledge spiral about himself and others. It is influenced both by experience and social relationships with the adults in their lives. If there are problems or language disorders of children, then it would also interfere with social development.

Since one of the important developmental tasks is the training and experience necessary preliminary to be a member of a "group" (Hurlock: 117). The group in question is a playmate; to communicate with friends is language. If a child's language development problems or disturbed.

\section{DISCUSSION \\ Language and Social Problems in Childhood}

Language is a system of symbols to communicate with others, including creativity and system rules. With the creative power of man can create a wide range of meaningful sentences with wanting a set of words and rules that limited. Thus the human language is a creative effort that never stops (Nurbiana Deani, et al: 2014).

Through human language and communication can interact to propose the results of his thinking and be able to express his feelings. With the language can open up the minds and develop insights. Language development for early childhood includes four developments such as listening, speaking, reading and writing (Rusniah: 2016). The development should be balanced in order to obtain the development of optimal read and write.

Children learn language through interaction with the environment, home environment, school or community. At school, children learn language through interaction with teachers, peers, and other adults. Teachers or early childhood educators need to understand about the development and language problems as well as developmental and social problems of early childhood.

According to Plato, potentially (nature) man is born as social beings (Zoon Policori). Syamsudin (1995: 105) proposed that "socialization is the process of learning to be social beings". "Socialization is a process in which individuals (especially) children train his sensitivity to social stimuli, especially the pressures and demands of life (the group) as well as learn to get along and behave, like others in the social environment". Because human social beings that need socialization, socialization is one means of communication is language. If the language of the child 
has problems, such as delayed speech, difficulty expressing words, it will also interfere with the child's social development.

Delay and hazards (noise) in speech development in children

1. Many of the causes of speech delay in children generally is the low level of intelligence that can keep children may learn to speak as good as his peers, that intelligence is normal or high lack of motivation for children to know that they can communicate adequately with form of pre-talking urge parents / people adult, limited access to practice speaking because of tight restrictions on how much they are allowed to speak at home.

2. One cause is undoubtedly the most common and most serious is the inability to encourage / motivate children to talk, even when the child started chattering. If the child is not given stimulation (stimulation) are encouraged to chattering, it will hinder the use of in-language / vocabulary is good and right.

3. Disadvantages of the impetus is a serious cause of speech delay child seen from the fact that if parents do not only talk to their children but also use a vocabulary that is more extensive and varied, while the child's ability in speaking that is growing very rapidly and quickly is an example: children from the middle class is more or whose parents wanted to send their (children) learn to speak earlier (fast) and better. Much less likely to experience delays in speaking to a child. While children from lower class whose parents are unable to provide the impetus for them, whether a lack of time / because they do not realize how important a child's speech development in such learners.

\section{THEORETICAL REVIEW \\ The concept of Social Skills}

Social skills are a form of behavior, actions and attitude displayed by individuals when interacting with others along with accuracy and speed so as to provide comfort for those who are around (Chaplin in Suhartini, 2004: 18)

1. Concept Speaking Skills

According to the theory of learning (Rachmat 1986: 282), children acquire knowledge of the language through three processes: the association, imitation and edification. Association means make a sound with a particular object. Imitation means mimicking the pronunciation and sentence structure are heard. Affirmation is intended as an expression of joy is expressed when children pronounce words correctly. Talking is a developing language skills in a child's life are preceded by the skills of listening, in the ability to speak or studied. Speaking of course closely related to the development of children's vocabulary obtained through listening and reading activities. Prior to mature in language development is also a delay in speaking activities.
Language and Social Issues in Early Childhood (Observation in One Child in kindergarten IT Ar-Rahmah Padang)

Observations do is observing kindergarten IT ArRahmah, which consists of three class B. From obesrvation and interviews with teachers were found 6 children with problems of language and social development. the problem that could be found was there were 3 children who speak unclear or lisp, 2 stammer is not smooth and the first people who have difficulty speaking (interviews with teachers and parents).

The research object 3 children and 2 that slurred speech stammering, from the observation that they belong to children who are active and very gregarious. In contrast to the first child to be hard to talk i.e. Ts in socializing with friends looks less and prefers to play alone.

No parents who do not want their children to succeed. No teacher / educator who do not want their students succeed. Language is not the only determinant of the success of the child. But good communication in general can lead people towards better communications seccessful. On contrary always triggers the onset of a problem for someone. Therefore, children need to be guided and trained to communicate well since. Problems at the beginning of the interview Ts are known to go to school, because he should be at level B but because Ts tough talk, especially new vocabulary of his parents agreed Ts entering kindergarten $\mathrm{A}$.

Parents were told the problem that existed. According to his mother, language development and social Ts seem to differ from 3-year-old sister. Her sister was already fluent and easy to socialize with new people (Khotijah: 2016). The findings of the observation that the Ts (observation object) language and social development is not in accordance with his age. Ts is difficult to respond to the questions asked or said to others, it also affects social development, such as Ts cannot play with his friends. At the beginning of the school entrance Ts prefer to follow where the class teacher to go and look less comfortable with her friends.

According K. Eileen Allen (151) there are some characteristics of speech and language development in children aged 5 years; that is:

1. Mastering 1500 words or more

2. Telling stories that he knew when they see an image in the picture.

3. Mention the usefulness of something; ball for bounced, a bed to sleep.

4. Recognize and name four to eight colors.

5. Understand simple jokes, making up jokes and puzzles.

6. Uttered by five to seven words; also sentences longer.

7. Mention the name of the city where he lives, birthday, and his parents' names.

8. Answer the phone correctly, call the people you call or receive short messages.

9. Say the sentences are almost incomprehensible in its entirety.

10. Using the word "may I" appropriately. 
The development of the social role of children aged 5 years according K. Eileen (152) are:

1. Liked friendship; often have one or two special playmates.

2. Share toys, take turns, play and do activities together with other children.

3. Full of love and attention, especially in children who are smaller or injury and the injured animals.

4. Following the instructions and perform tasks nearly every time; generally, do whatever is asked of parents or teachers.

5. Still need a sense of comfort and reassurance from the adult, but has become more open in seeking and accept the comfortable feeling.

6. Have a better self-control less the rebound-surge of emotion.

7. Loves to tell jokes, entertain and make people laugh.

8. Like arrogancy on something.

From the characteristics of language development and social by K. Eileen above, many of the points that did not exist in the child Ts that there should be according to age. According to the mother's explanation that the Ts have dyslexia, it is known from information on the internet. This however cannot be accounted for parents not perform the expert examination. Dyslexia is a difficulty in reading children under the supposed ability to consider intelligent level, age and education. There are also some symptoms of dyslexia (by Elis Supartini and Wati Early in Sustainable Profession Development module) is:

a) Unable to pronounce the rhythm of the words correctly and proportionately.

b) The difficulty in sorting letters in the word.

c) Difficult voiced phonemes (units of sound) and combine them into a single word.

d) It is hard to spell correctly. It might even children will spell one word with various sayings.

e) It is hard to spell words or syllables correctly.

Factors that cause dyslexia are:

1) heredity

Dyslexia is more likely in families that have a member lefty. However, parents who dyslexia do not automatically lower this disorder in their children, or a left-handed child must have dyslexia.

2) Hearing problems since the age of din

If you have trouble hearing occurs early and does not detect, the developing brain will be difficult to connect the sound or voice heard with letters or words it sees. meanwhile, the development of the ability to hear is crucial for the development of language skills can eventually lead to long-term difficulties. Consultation and handling specialists would be required.

3) factors Combines

Which is a combination of two of the above? This combination of factors led to the dyslexic child becomes more serious or severe; it may well be thorough and continuous handling.
Nuisance / danger in speech development in children, namely:

1. The weakness in speaking (speaking) vocabulary

2. Slow to develop a language / in speaking

3. Often talking irregular

4. No concentration on receiving a word (language) of parents / teachers.

A. Measures Troubleshooting and Social Language in Early Childhood

There are several approaches undertaken in children with developmental language disorders, which are:

a) Task Analysis Approach

Is an approach that is applied in the response to language difficulties. This approach aims to improve children's language ability difficulties (syntax and morphology) and function of language (pragmatic) in facing the tasks outlined in detail.

b) behavioral approach

To overcome language problems experienced by children who has difficulties in language with the language change behavior and language and communication are shown to make children know about behavior modification. In the producer practice, this approach is done by taking into account the child interpersonal interaction with peers or people who were in the vicinity, and the verbal utterances which are shown by the child.

\section{B. Process Approach}

The process approach is an approach that aims to strengthen and normalize the processes related to the basic process is the process of language acquisition language and the language express.

C. Interpersonal Approach Interactive

Interpersonal approach is interactive (interactive personal approach) aims to strengthen pragmatic language skills in the field and develop the communication skills of children have difficulties in language

On the issue of Children with problems, language disorders actions to be taken to the school is:

1. Stimulus give the intense, with trains to many repeat noun or new vocabulary.

2. Communicating with parents about child development that is experiencing the problem of language development.

3. Suggest to parents to check children are impaired to the experts, in order to know the language and social development disorders.

4. In social issues, ask classmates child who disturbed the language to always ask him in conducting play IV. 


\section{CONCLUSION AND SUGGESTION Conclusion}

Language is an important tool in the social development of children, because children's language can communicate with those around him. Because human social beings that need socialization, socialization is one means of communication is language. If the language of the child has problems, such as delayed speech, difficulty expressing words, it will also interfere with the child's social development.

The development of language and social problems in early childhood in this paper the authors discuss the results of observation. The findings of the observation that the Ts (observation object) language and social development is not in accordance with his age. Ts is difficult to respond to the questions asked or said to others, it also affects social development, such as Ts cannot play with his friends. At the beginning of the school entrance Ts prefer to follow where the class teacher to go and look less comfortable with her friends.

To overcome the problem of language development and social development, there must be cooperation between the school and parents. The school also needs stimulation to children who have language development and social issues. To know the language and social problems of children parents should conduct further investigation to child development experts.

\section{Suggestion}

Recognizing the limitations of the writer is far from perfect; the future will be more focused and detailed in explaining about the paper on top with sources more and accountable. The authors hope their helpful addition of experts in charge of the development of language in early childhood for the perfection of this paper. In reference should be more widely read national or international journals that discuss the development and the disorder can be in early childhood. As well as this paper could be one of the references relating to the issue of development and language disorders in early childhood.

\section{REFERENCES}

[1] Allen,K Eileen., Martoz ,Lynn R Profil Perkembangan Anak Pra Kelahiran Hingga Usia 12 Tahun, edisi 5. Indeks.

[2] Benson, Janette B, Haith,Marshah M. Language, Memory and Cognition in fancy and Early Childhood

[3] Crain,William. (2007), Teori Perkembangan; Konsep dan Aplikasi, Yogyakarta. Pustaka Pelajar

[4] Dhieni, Nurbiana, Fridani,Lala. Modul; Hakikat Perkembangan Bahasa Anak
[5] Hurlock, Elizabeth B. (2002), Psikologi Perkembangan Pendekatan Sepanjang Rentang Kehidupan, Jakarta. Penerbit Erlangga

[6] Khotijah, (2016), Strategi Pengembangan Bahasa Pada Anak Usia Dini.Elementary Vol. 2 Edisi 2 Juli 2016

[7] Rusniah, Meningkatkan Perkembangan Bahasa Indonesia Anak Usia Dini Melalui Penggunaan Metode Bercerita Pada Kelompok a Di TK Malahayati Neuhen Tahun Pelajaran 2015/2016. Jurnal Edukasi-Jurnal Bimbingan Konseling,

[8] Sadulloh, Uyoh,Robandi, Bambang, Muharram,Agus . (2017). Pedagogik, Bandung,Cipta Utama

[9] Suryabarata,Sumadi. (2010), Psikologi Kepribadian, Jakarta, PT Raja Grafindo Persada

[10] Suryana, Dadan (2013), Pendidikan Anak Usia Dini; Teori dan Praktik Pembelajaran,Padang,UNP Press

[11] Supartini,Elis,Wati,Dini. (2017). Modul Pengembangan Keprofesian Berkelanjuta; Terintegrasi Penguatan Pendidikan Karakter; Bidang Taman Kanak-Kanak Kelompok Kompetensi A; Pedagogik, Bandung, PPPPTK TK dan PL 